\title{
ANALISIS FAKTOR FAKTOR YANG MEMPENGARUHI KEBIJAKAN DEVIDEN DENGAN QUICK RATIO SEBAGAI VARIABEL MODERATING PADA PERUSAHAAN MANUFAKTUR YANG TERDAFTAR DI BURSA EFEK INDONESIA TAHUN 2008 - 2012
}

\author{
Oleh : \\ Elly Susanti \\ Dosen STIE Sultan Agung
}

\begin{abstract}
Abstraksi
Tujuan dari Penelitian ini adalah untuk membuktikan dan menganalisis pengaruh Ukuran Perusahaan, Arus Kas Operasi, PBV, dan PER baik secara parsial maupun simultan terhadap DPR pada perusahaan manufaktur yang terdaftar pada Bursa Efek Indonesia, dan juga untuk membuktikan dan menganalisis apakah Quick Ratio mampu memoderasi hubungan antara variabel Ukuran Perusahaan, Arus Kas Operasi, PBV dan PER terhadap DPR. Populasi dari penelitian ini sebanyak 139 perusahaan manufaktur yang terdaftar di Bursa Efek Indonesia (BEI) tahun 2008 - 2012. Sampel diseleksi dengan menggunakan metode purposive sampling sebanyak 33 perusahaan. Untuk hipotesis pertama menggunakan analisis regresi berganda sedangkan untuk hipotesis kedua menggunakan analisis residual. Penelitian ini menunjukkan hasil dari hipotesis pertama Ukuran Perusahaan, Arus Kas Operasi, PBV, dan PER secara simultan berpengaruh terhadap DPR. Secara parsial hanya PER yang berpengaruh signifikan terhadap DPR. Selanjutnya Quick Ratio digunakan sebagai variabel moderating hasilnya adalah Quick Ratio mampu memperkuat hubungan PER terhadap pengaruh DPR dan memperlemah hubungan Ukuran Perusahaan, Arus Kas Operasi, PBV terhadap pengaruh DPR.
\end{abstract}

Kata Kunci: DPR, Ukuran Perusahaan, Arus Kas Operasi, PBV, PER, Quick Ratio

\section{Abstraction}

The aim of the research is to analyze and prove of partially and simultaneously the influence of Size, Operation Cash Flow PBV and PER on DPR. It also aims at analyzing influence of Size of compaines, Operation Cash Flow PBV and PER with Quick Ratio as a moderating variable and DPR. Population of this research amount to 139 manufacturing companies listed on the Indonesia Stock Exchange on 2008 - 2012. The sample is selected using purposive sampling method amount to 33 companies. This data is processed on SPSS software using linear multiple regression for the first hypothesis and residual method test for the second hypothesis. This research show the result from the firts hypothesis, Size of Companies, Operation Cash Flow PBV and PER simultaneously affect DPR. Partially, only variabel PER is significantly to DPR. While Quick Ratio is used as the moderating variable at second examine, and the result is it can strenghtened PER that influence DPR, but weakened Size of Companies, Operation Cash Flow PBV toward DPR.

Keywords : DPR, Size of Companies, Operation Cash Flow, PBV, PER, Quick Ratio

\section{A. PENDAHULUAN}

\section{Latar Belakang Masalah}

Investor perlu mempertimbangkan dengan sebaik baiknya ke perusahaan mana modal akan ditanamkan, oleh sebab itu para investor memerlukan laporan keuangan perusahaan dimana mereka akan menanamkan modalnya guna melihat prospek perusahaan di masa yang akan datang. Pada dasarnya investor mempunyai tujuan utama dalam menanamkan modalnya ke dalam perusahaan yaitu mencari pendapatan atau tingkat pengembalian investasi (return) baik berupa pendapatan deviden (dividen yield) maupuan pendapatan dari selisih harga jual saham terhadap harga belinya (capital gain). Dalam hubungannya dengan pendapatan deviden, para investor menginginkan pembayaran deviden secara stabil dari waktu ke waktu. Hal ini mencerminkan kondisi keuangan perusahaan tersebut juga stabil dan sebaliknya, perusahaan dengan deviden tidak stabil mencerminkan kondisi keuangan perusahaan yang kurang baik.

Kebijakan deviden merupakan keputusan atau kebijakan untuk menentukan berapa banyak deviden yang harus dibagikan kepada pemegang saham. Kebijakan deviden mempunyai arti penting bagi perusahaan. Studi terdahulu mengenai kebijakan deviden diantaranya Dyckman (2001) menemukan faktor faktor yang mempengaruhi kebijakan deviden yaitu lingkungan internal perusahaan atau yang dapat dikontrol manajemen, 
seperti posisi likuiditas, hutang, profitabilitas yang merupakan unsur dari kinerja keuangan, dan lingkungan eksternal perusahaan atau diluar kontrol perusahaan, antara lain seperti inflasi, pajak atas deviden, hukum dan lain sebagainya, dimana perusahaan harus selalu menyesuaikan diri terhadap perubahan faktor faktor tersebut. Tabel 1 memberikan gambaran tentang persentase rasio keuangan (ukuran perusahaan, arus kas operasi, Price To Book Value (PBV), Price Earning Ratio (PER), quick ratio) selama tahun 2008 - 2012 untuk perusahaan manufaktur yang terdaftar di BEI.

Tabel 1

Rata rata Dividend Payout Ratio, Ukuran perusahaan, Arus Kas Operasi, PBV, PER, Quick Ratio selama tahun 2008 - 2012

\begin{tabular}{|c|c|c|c|c|c|}
\hline $\begin{array}{c}\text { Keteranga } \\
\mathbf{n} \\
\end{array}$ & 2008 & 2009 & 2010 & 2011 & 2012 \\
\hline $\begin{array}{l}\text { Dividend } \\
\text { Payout } \\
\text { Ratio }\end{array}$ & 0,92 & 0,46 & 0,58 & 12,65 & 28,70 \\
\hline $\begin{array}{l}\text { Ukuran } \\
\text { Perusahaan }\end{array}$ & $\begin{array}{c}27,9 \\
3\end{array}$ & $\begin{array}{c}28,1 \\
0\end{array}$ & $\begin{array}{c}28,2 \\
1\end{array}$ & 28,37 & 28,50 \\
\hline $\begin{array}{l}\text { Arus Kas } \\
\text { Operasi }\end{array}$ & $\begin{array}{c}26,1 \\
4 \\
\end{array}$ & $\begin{array}{c}26,0 \\
2 \\
\end{array}$ & $\begin{array}{c}26,0 \\
1\end{array}$ & 25,84 & 26,39 \\
\hline PBV & 3,48 & $\begin{array}{c}44,4 \\
0\end{array}$ & $\begin{array}{c}- \\
8,09\end{array}$ & $\begin{array}{c}186,2 \\
0\end{array}$ & $\begin{array}{c}216,2 \\
2\end{array}$ \\
\hline PER & $\begin{array}{c}12,8 \\
8\end{array}$ & $\begin{array}{c}- \\
66,0 \\
4\end{array}$ & $\begin{array}{c}46,4 \\
2\end{array}$ & $\begin{array}{c}381,0 \\
2\end{array}$ & $\begin{array}{c}611,1 \\
5\end{array}$ \\
\hline $\begin{array}{l}\text { Quick } \\
\text { Ratio }\end{array}$ & 1,84 & 2,13 & 2,47 & 2,44 & 2,24 \\
\hline
\end{tabular}

Sumber : www.idx.co.id (data diolah)

Dari tabel 1 di atas, dilihat setiap kenaikan Ukuran Perusahaan manufaktur yang diteliti tahun 2008 - 2012 diikuti dengan kenaikan Dividend Payout Ratio. Fenomena ini sejalan dengan Penelitian yang dilakukan oleh Lopolusi (2013) yang menjelaskan pengaruh signifikan antara Ukuran perusahaan dengan Dividend Payout Ratio.

Dari tabel 1 di atas, menunjukkan adanya perbedaan trend kenaikan dan penurunan Arus Kas Operasi terhadap Dividend Payout Ratio yang terjadi setiap periode. Fenomena ini tidak sesuai dengan penelitian yang dilakukan oleh Manurung (2009) yang menjelaskan bahwa Arus Kas Operasi mempunyai pengaruh yang signifikan terhadap Dividend Payout Ratio. Hasil penelitian yang dilakukan tersebut juga berbeda dengan hasil temuan penelitian yang dilakukan oleh Irawan \& Nurdhiana (2012) yang menjelaskan bahwa adanya tidak ada pengaruh antara Arus Kas Operasi dengan Dividend Payout Ratio

Tabel 1 di atas, menunjukkan adanya perbedaan trend kenaikan dan penurunan PBV terhadap Dividend Payout Ratio yang terjadi setiap periode. Fenomena ini sejalan dengan hasil penelitian yang dilakukan oleh Mariah (2012) dan Purwanti (2012) yang menjelaskan tidak ada pengaruh antara PBV dengan Dividend Payout Ratio.
Tabel 1 di atas, menunjukkan adanya perbedaan trend kenaikan dan penurunan PER terhadap Dividend Payout Ratio yang terjadi setiap periode. Dari tabel 1 di atas, menunjukkan adanya perbedaan trend kenaikan dan penurunan Quick Ratio terhadap Dividend Payout Ratio yang terjadi setiap periode. Fenomena ini sejalan dengan Penelitian yang dilakukan oleh Lopolusi (2013) yang menjelaskan tidak ada pengaruh antara Quick Ratio terhadap Dividend Payout Ratio.

\section{Rumusan Masalah}

Berdasarkan latar belakang masalah di atas penelitian ini memiliki rumusan masalah sebagai berikut :

a. Apakah ada pengaruh Ukuran Perusahaan, Arus Kas Operasi, Price to Book Value dan Price Earning Ratio terhadap Dividend Payout Ratio baik secara parsial maupun secara simultan?

b. Apakah Quick Ratio mampu memperkuat atau memperlemah hubungan antara Ukuran Perusahaan, Arus Kas Operasi, Price to Book Value dan Price Earning Ratio terhadap Dividend Payout Ratio ?

\section{Tujuan Penelitian}

Penelitian ini memiliki dua tujuan utama. Pertama, untuk mengetahui dan menganalisis pengaruh Ukuran Perusahaan, Arus Kas Operasi, Price to Book Value, Price Earinng Ratio terhadap Devidend Payout Ratio baik secara parsial maupun simultan pada perusahaan Manufaktur di Bursa Efek Indonesia tahun 2008 - 2012. Kedua, mengetahui dan menganalisis apakah Quick Ratio mampu memoderasi hubungan antara Ukuran Perusahaan, Arus Kas Operasi, Price to Book Value, Price Earning Ratio terhadap Dividend Payout Ratio.

\section{Metode Penelitian}

Desain penelitian yang digunakan adalah penelitian asosiatif, yaitu untuk menganalisis hubungan antara satu variabel dengan variabel lainnya atau bagaimana suatu variabel mempengaruhi variabel lain. Teknik pengambilan sampel yang digunakan oleh penelitian adalah metode purposive sampling. Metode pengumpulan data yang digunakan adalah melalui studi dokumen. Data yang dipakai dalam penelitian ini adalah data sekunder yang diteliti pada situs resmi www.idx.co.id. model teknik analisis data yang digunakan dalam penelitian ini dilakukan dengan pendekatan teknik analisis regresi linier berganda dan uji hipotesis seperti ui $\mathrm{t}$ dan uji $\mathrm{F}$ untuk hipotesis pertama sedangkan untuk hipotesis kedua menggunakan uji residual.

\section{A. LANDASAN TEORI}

1. Kebijakan Deviden

Kebijakan deviden merupakan keputusan pembayaran deviden yang mempertimbangkan maksimalisasi harga saham saat ini dengan periode mendatang. Sudana (2011) menyebutkan ada tiga teori dari prefensi investor antara lain : 1). Teori 
Dividend Irrelevance, 2). Teori Bird In-the-Hand 3). Teori Tax Preference.

\section{Dividend Payout Ratio}

Dividend payout ratio adalah persentase dari pendapatan yang akan dibayarkan kepada pemegang saham sebagai "cash dividend". Dividend payout ratio merupakan perbandingan antara dividend per share dengan earning per share pada periode yang bersangkutan $\mathrm{Di}$ dalam komponen dividend per share terkandung unsur dividen, sehingga jika semakin besar. dividend yang dibagikan maka semakin besar pula dividend payout rationya. Pembagian dividen yang besar bukanya tidak diinginkan oleh investor, tetapi jika dividend payout ratio lebih besar dari $25 \%$ dikuatirkan akan terjadi kesulitan likuiditas keuangan perusahaan dimasa yang akan datang. Banyak perusahaan berusaha untuk mempertahankan dividend payout ratio, pendapatan yang diinginkan untuk suatu periode yang panjang, artinya terdapat target dividend payout ratio untuk jangka panjang atau mempertahankan pendapatan. Hasilnya, dividen biasanya dipertahankan pada jumlah konstan dan dinaikkan hanya jika manajer yakin bahwa relatif mudah untuk mempertahankan kenaikan pembayaran tersebut di masa depan

\section{Ukuran Perusahaan}

Ukuran perusahaan, faktor ini menjelaskan bahwa suatu perusahaan besar memiliki akses yang lebih mudah ke pasar modal, sedangkan perusahaan kecil tidak mudah. Kemudahan aksesibilitas ke pasar modal merupakan fleksibilitas dan kemampuan perusahaan untuk menciptakan hutang atau memunculkan dana yang lebih besar dengan catatan perusahaan tersebut memiliki ratio pembayaran dividen yang lebih tinggi daripada perusahaan kecil.

\section{Arus Kas Operasi}

Menurut Sudana (2011) Arus kas operasi adalah kas yang berasal dari aktivitas bisnis perusahaan yang normal. Untuk menghitung arus kas operasi didasarkan pada penjualan dikurangi biaya, tetapi tidak memperhitungkan penyusutan karena bukan merupakan pengeluaran kas, dan juga tidak memperhitungkan biaya bunga karena merupakan pengeluaran untuk pendanaan. Aktivitas operasi menimbulkan pendapatan dan beban dari operasi utama suatu perusahaan. Karena itu aktivitas operasi mempengaruhi laporan laba rugi, yang dilaporkan dengan dasar akrual.

\section{Price to Book Value (PBV)}

PBV adalah perbandingan antara harga saham dengan Book Value-nya (BV), dimana BV dihasilkan dari ekuitas dibagi rata-rata jumlah saham yang beredar. Konsep penggunaannya pun sama dengan PER: semakin tinggi nilai PBV, maka semakin mahal harga sahamnya.

\section{Price Earning Ratio (PER)}

PER adalah perbandingan antara harga saham dengan laba bersih perusahaan, dimana harga saham sebuah emiten dibandingkan dengan laba bersih yang dihasilkan oleh emiten tersebut dalam setahun. Karena yang menjadi fokus perhitungannya adalah laba bersih yang telah dihasilkan perusahaan, maka dengan mengetahui PER sebuah emiten, maka dapat diketahui apakah harga sebuah saham tergolong wajar atau tidak secara real dan bukannya secara future alias perkiraan.

\section{Quick Ratio}

Quick Ratio menurut Brigham and Houtson (2007) rasio ini dihitung dengan mengurangi persediaan dari aset lancar, kemudian membagi sisanya dengan kewajiban lancar. Persediaan pada umumnya merupakan aset lancar perusahaan yang tidak likuid sehingga persediaan merupakan aset, dimana kemungkinan besar akan terjadi kerugian jika terjadi likuidasi. Oleh karena itu, rasio yang mengukur kemampuan suatu perusahaan untuk membayar kewajiban jangka pendek tanpa mengandalkan penjuangan persediaan sangat penting artinya.

\section{B. PEMBAHASAN}

\section{Pembahasan Hasil Analisis Data Hipotesis Pertama \\ a. Persamaan Regresi}

Pengujian Hipotesis dapat dilakukan setelah diadakan pengujian asumsi klasik. Pengujian hipotesis pertama ini menggunakan analisis regresi berganda, dengan cara menguji apakah Ukuran Perusahaan, AKO, PBV dan PER berpengaruh terhadap DPR baik secara simultan maupun secara parsial. Pengaruh yang ditimbulkan ini terlihat pada tabel 6 sebagai berikut :

Tabel 6

Hasil Analisis Regresi Hipotesis Pertama Coefficients $^{\mathrm{a}}$

\begin{tabular}{|ll|r|r|}
\hline \multirow{2}{*}{ Model } & \multicolumn{2}{|c|}{ Unstandardized Coefficients } \\
\cline { 2 - 4 } & \multicolumn{2}{|c|}{ B } & \multicolumn{1}{c|}{ Std. Error } \\
\hline 1 & (Constant) & 3,003 & 4,082 \\
& LN_UK & $-1,957$ & 1,647 \\
& LN_AKO &, 151 & 1,212 \\
& LN_PBV &, 048 &, 095 \\
& LN_PER &, 892 &, 122 \\
\hline
\end{tabular}

Sumber : Data Diolah (2013)

Dari tabel cofficient diatas maka model regresi yang dapat dibentuk adalah sebagai berikut : LN_DPR $=3,003-1,957 \mathrm{LN} \_U K+0,151 \mathrm{LN} \_\mathrm{AKO}$

$$
+0,048 \text { LN_PBV + 0,892 LN_PER + e }
$$

Model regresi di atas, dapat diinterprestasikan sebagai berikut :

a. Constant $=3,003$

Nilai konstanta ini menunjukkan bahwa apabila variabel independen Ukuran perusahaan, Arus Kas Operasi, PBV, PER diasumsikan bernilai 
nol, maka nilai dari Dividend Payout Ratio adalah sebesar 3, 003 .

b. $b_{1}=-1,957$

Koefisien regresi $b_{1}$ menunjukkan bahwa setiap variabel Ukuran Perusahaan meningkat sebesar satu satuan, maka Dividend Payout Ratio akan menurun sebesar 1,957 atau $195,7 \%$ dengan asumsi variabel independen lainnya dianggap tetap atau sama dengan nol

c. $b_{2}=0,151$

Koefisien regresi $b_{2}$ menunjukkan bahwa setiap variabel Arus Kas Operasi meningkat sebesar satu satuan, maka Dividend Payout Ratio akan bertambah sebesar 0,151 atau 15,1\% dengan asumsi variabel independen lainnya dianggap tetap atau sama dengan nol

d. $\mathrm{b}_{3}=0,048$

Koefisien regresi $b_{3}$ menunjukkan bahwa setiap variabel PBV meningkat sebesar satu satuan, maka Dividend Payout Ratio akan bertambah sebesar 0,048 atau 4,8\% dengan asumsi variabel independen lainnya dianggap tetap atau sama dengan nol

e. $\mathrm{b}_{4}=0,892$

Koefisien regresi $b_{4}$ menunjukkan bahwa setiap variabel PER meningkat sebesar satu satuan, maka Dividend Payout Ratio akan bertambah sebesar 0,892 atau 89,2 \% dengan asumsi variabel independen lainnya dianggap tetap atau sama dengan nol

\section{b. Pengujian Hipotesis}

1) Koefisien Determinasi

Untuk meyakinkan hubungan atau tingkat kekuatan hubungan antar variabel dapat dilihat pada uji koefisien determinasi pada tabel 7 sebagai berikut :

Tabel 7

Koefisien Determinasi Hipotesis Pertama Model Summary ${ }^{\mathrm{b}}$

\begin{tabular}{|l|r|r|r|c|}
\hline Model & $\mathrm{R}$ & $\mathrm{R}$ Square & \multicolumn{1}{|c|}{$\begin{array}{c}\text { Adjusted R } \\
\text { Square }\end{array}$} & $\begin{array}{l}\text { Std. Error of the } \\
\text { Estimate }\end{array}$ \\
\hline 1 &, $769^{\mathrm{a}}$ &, 591 &, 579 &, 85524 \\
\hline
\end{tabular}

Sumber :Data Diolah (2013)

Tabel 7 memperlihatkan bahwa nilai Adjust $\mathrm{R}^{2}$ sebesar 0,579 atau sebesar $57,9 \%$ yang berarti bahwa persentase pengaruh variabel independen terhadap Dividend Payout Ratio sebsar nilai koefisien determinasi 57,9\% sedangkan sisanya $42,1 \%$ dipengaruhi atau dijelaskan oleh variabel lain yang tidak dimasukkan pada dalam model penelitian ini. Nilai $\mathrm{R}$ merupakan koefisien korelasi dengan nilai 0,591 atau 59,1\% menunjukkan bahwa korelasi atau hubungan antara variabel independen Ukuran perusahaan, Arus Kas Operasi, PBV dan PER dengan variabel dependen yaitu Dividend Payout Ratio adalah kuat karena diatas $50 \%$.

\section{2) Uji Simultan (Uji Statistik F)}

Hasil pengujian statistik F (uji simultan) pada variabel Ukuran Perusahaan, Arus Kas Operasi,
PBV dan PER terhadap Dividend Payout Ratio diperoleh hasil sebagai berikut :

Tabel 8

Hasil Regresi Uji F

Model Summary ${ }^{b}$

\begin{tabular}{|c|c|c|c|c|c|c|}
\hline \multirow[b]{2}{*}{$\begin{array}{l}\text { Mode } \\
1\end{array}$} & \multicolumn{5}{|c|}{ Change Statistics } & \multirow[b]{2}{*}{$\begin{array}{c}\text { Durbin } \\
- \\
\text { Watso } \\
\mathrm{n}\end{array}$} \\
\hline & $\begin{array}{c}\mathrm{R} \\
\text { Square } \\
\text { Chang } \\
\mathrm{e}\end{array}$ & $\begin{array}{c}\text { F } \\
\text { Chang } \\
\mathrm{e}\end{array}$ & $\begin{array}{c}\mathrm{df} \\
1\end{array}$ & df2 & $\begin{array}{c}\text { Sig. F } \\
\text { Chang } \\
\mathrm{e}\end{array}$ & \\
\hline 1 & ,591 & 51,623 & 4 & $\begin{array}{r}14 \\
3\end{array}$ &, 000 & 1,847 \\
\hline
\end{tabular}

Sumber :Data Diolah (2013)

Dari Tabel 8 diperoleh nilai Fhitung sebesar 51,623 sedangkan Ftabel pada tingkat kepercayaan $\alpha=5 \%$ dengan df $1=\mathrm{k}-1=3$ dan df $2=165-4=$ 161 adalah sebesar 2,66 dengan tingkat signifikansi 0,000. Dengan demikian dapat disimpulkan, sig $=$ $0,000<\alpha=0,05$ yang berarti hipotesis menerima Ha yang menyatakan Ukuran perusahaan, Arus Kas Operasi, PBV, PER secara simultan berpengaruh signifikan terhadap Dividend Payout Ratio.

\section{3) Uji Parsial (Uji Statistik t)}

Hasil pengujian uji statistik t (Uji Parsial) pada Ukuran perusahaan, Arus Kas Operasi, PBV, PER terhadap Dividend Payout Ratio dapat dilihat pada Tabel 9.

\section{Tabel 9}

Hasil Regresi Uji t

\begin{tabular}{|c|c|c|c|}
\hline \multicolumn{2}{|c|}{ Model } & $\mathrm{T}$ & Sig. \\
\hline \multirow[t]{5}{*}{1} & (Constant) & ,736 & ,463 \\
\hline & LN_UK & $-1,188$ & ,237 \\
\hline & LN_AKO &, 125 & ,901 \\
\hline & LN_PBV & ,506 & 614 \\
\hline & LN_PER & 7,293 & ,000 \\
\hline
\end{tabular}

Sumber :Data Diolah (2013)

Kriteria pengambilan keputusan menggunakan taraf nyata $5 \%$ untuk uji dua arah $(\alpha / 2=0,05 / 2=0,025)$ dengna derajat bebas $(\mathrm{df}) \mathrm{n}-$ $\mathrm{k}=165-4=161$. Nilai $\mathrm{t}$ tabel dengan taraf nyata $\alpha / 2=0,025$ dan $\mathrm{df}=161$ adalah 1,97481

a. Jika $\mathrm{t}$ hitung $>\mathrm{t}$ tabel $(1,97481)$ atau $\mathrm{t}$ hitung $<\mathrm{t}$ tabel $(-1,97481)$, maka $\mathrm{Ha}$ yang diajukan diterima (berpengaruh).

b. Jika $\mathrm{t}$ tabel $(-1,97481) \leq \mathrm{t}$ hitung $\leq \mathrm{t}$ tabel $(1,97481)$, maka Ha tidak dapat diterima (tidak berpengaruh).

Berdasarkan pengujian pada tabel 5 maka secara parsial pengaruh masing masing variabel independen terhadap variabel dependen dapat diuraikan sebagai berikut :

a. Variabel Ukuran Perusahaan mempunyai t hitung $=-1,188<\mathrm{t}$ tabel $=1,97481$ dengan tingkat signifikansi sebesar 0,237 sehingga dapat disimpulkan variabel Ukuran Perusahaan tidak 
berpengaruh secara signifikan terhadap Dividend Payout Ratio pada Perusahaan Manufaktur yang terdaftar di Bursa Efek Indonesia tahun 2008 2012. Kondisi ini berarti Ha tidak dapat diterima

b. Variabel Arus Kas Operasi mempunyai t hitung $=0,125<\mathrm{t}$ tabel $=1,97481$ dengan tingkat signifikansi sebesar 0,901 sehingga dapat disimpulkan variabel Arus Kas Operasi tidak berpengaruh secara signifikan terhadap Dividend Payout Ratio pada Perusahaan Manufaktur yang terdaftar di Bursa Efek Indonesia tahun 2008 - 2012. Kondisi ini berarti Ha tidak dapat diterima

c. Variabel PBV mempunyai t hitung $=0,506<\mathrm{t}$ tabel $=1,97481$ dengan tingkat signifikansi sebesar 0,614 sehingga dapat disimpulkan variabel PBV tidak berpengaruh secara signifikan terhadap Dividend Payout Ratio pada Perusahaan Manufaktur yang terdaftar di Bursa Efek Indonesia tahun 2008 - 2012. Kondisi ini berarti Ha tidak dapat diterima

d. Variabel PER mempunyai t hitung $=7,293>\mathrm{t}$ tabel $=1,97481$ dengan tingkat signifikansi sebesar 0,000 sehingga dapat disimpulkan variabel PER berpengaruh positif dan signifikan terhadap Dividend Payout Ratio pada Perusahaan Manufaktur yang terdaftar di Bursa Efek Indonesia tahun 2008 - 2012. Kondisi ini berarti Ha diterima.

\section{Uji Hipotesis Kedua}

Pengujian Hipotesis kedua ini menggunakan analisa regresi berganda dengan uji residual. Pengujian hipotesis kedua ini dilakukan untuk menguji variabel moderating yang digunakan dalam penelitian ini adalah Quick Ratio apakah dapat memoderasi hubungan antara variabel independen (Ukuran Perusahaan, Arus Kas Operasi, PBV, PER) dengan variabel dependen (Dividend Payout Ratio). Hasil persamaan uji residual dalam penelitian ini dapat dilihat sebagai berikut:

Tabel 10

Hasil Pengujian Pengaruh Ukuran Perusahaan, Arus Kas Operasi, PBV dan PER terhadap Quick Ratio Coefficients $^{\mathrm{a}}$

\begin{tabular}{|l|r|r|}
\hline \multirow{2}{*}{ Model } & \multicolumn{2}{|c|}{ Unstandardized Coefficients } \\
\cline { 2 - 3 } 1 (Constant) & B & \multicolumn{1}{|c|}{ Std. Error } \\
LN_UK & 15,382 & 3,756 \\
LN_AKO & $-3,036$ & 1,516 \\
LN_PBV & $-1,647$ & 1,116 \\
LN_PER &,- 143 &, 087 \\
\hline
\end{tabular}

Sumber : Data diolah (2013)

Model pertama yang dapat dikembangkan dari hasil penelitian hipotesis kedua ini adalah : $\mathrm{M}=$ 15,382 - 3,036LN_UK - 1,647LN_AKO $0,143 \mathrm{LN} \_P B V+0,303 \mathrm{LN} \_P E R$
Model pertama untuk hipotesis kedua bertujuan untuk mendapatkan nilai residual dari variabel moderating. Nilai residual dari model pertama digunakan sebagai variabel dependen pada model kedua. Dari hasil uji model kedua akan diperoleh kesimpulan apakah variabel Quick Ratio bisa dikatakan sebagai variabel moderating atau tidak. Sebuah variabel dikatakan sebagai variabel moderating jika memiliki nilai koefisien negatif dan berpengaruh signifikan.

Hasil pengujian model kedua dapat dilihat pada Tabel 11 berikut ini:

Tabel 11

Hasil Pengujian Regresi Hipotesis Kedua Coefficients $^{\mathrm{a}}$

\begin{tabular}{|c|c|c|c|c|c|c|c|}
\hline \multirow[b]{2}{*}{ Model } & \multicolumn{2}{|c|}{$\begin{array}{c}\text { Unstand } \\
\text { ardized } \\
\text { Coefficie } \\
\text { nts }\end{array}$} & \multirow{2}{*}{$\begin{array}{c}\begin{array}{c}\text { Standa } \\
\text { rdized } \\
\text { Coeffic } \\
\text { ients }\end{array} \\
\\
\text { Beta }\end{array}$} & \multirow[b]{2}{*}{$\mathrm{t}$} & \multirow[b]{2}{*}{$\begin{array}{l}\mathrm{Si} \\
\text { g. }\end{array}$} & \multicolumn{2}{|c|}{$\begin{array}{c}\text { Collineari } \\
\text { ty } \\
\text { Statistics }\end{array}$} \\
\hline & B & $\begin{array}{l}\text { Std } \\
\text { E } \\
\text { Err } \\
\text { or }\end{array}$ & & & & $\begin{array}{l}\text { Toler } \\
\text { ance }\end{array}$ & \\
\hline $\begin{array}{c}1 \text { (Cons } \\
\tan t)\end{array}$ & $\begin{array}{r}, 62 \\
8\end{array}$ & $\begin{array}{r}, 03 \\
7\end{array}$ & & $\begin{array}{r}16, \\
78 \\
6\end{array}$ & $\begin{array}{l}, 0 \\
0 \\
0\end{array}$ & & \\
\hline $\begin{array}{l}\mathrm{LN}_{-} \\
\mathrm{DPR}\end{array}$ & $\begin{array}{r}- \\
, 05 \\
1\end{array}$ & $\begin{array}{r}, 02 \\
4\end{array}$ &,- 175 & $\begin{array}{r}- \\
2,1 \\
52\end{array}$ & $\begin{array}{l}, 0 \\
3 \\
3\end{array}$ & 1,000 & $\begin{array}{l}1, \\
00\end{array}$ \\
\hline
\end{tabular}

Sumber : Data diolah (2013)

Dari tabel 11 tersebut, maka model uji residual dapat diformulasikan dalam bentuk persamaan sebagai berikut :

$$
|\mathrm{e}|=0,628-0,051 \mathrm{LN} \_D P R
$$

Berdasarkan hasil uji statistik $t$ yang dilakukan diketahui bahwa nilai t signifikan sebesar $0,033<0,05$. Sebuah variabel dikatakan variabel moderating jika memiliki koefisien negatif dan berpengaruh signifikan. Dari angka tersebut, dapat disimpulkan bahwa variabel Quick Ratio merupakan variabel moderating yang mampu memoderasi hubungan antara Ukuran perusahaan, Arus Kas Operasi, PBV dan PER terhadap Dividend Payout Ratio.

\section{KESIMPULAN DAN SARAN}

\section{Kesimpulan}

a. Ukuran perusahaan, Arus Kas Operasi, PBV dan PER secara simultan memiliki pengaruh yang signifikan terhadap Dividend Payout Ratio pada Perusahaan Manufaktur yang terdaftar di BEI tahun 2008 - 2012.

b. Secara parsial PER berpengaruh positif dan signifikan terhadap Dividend Payout Ratio sedangkan Ukuran perusahaan, Arus Kas Operasi dan PBV secara parsial tidak memiliki pengaruh terhadap Dividend Payout Ratio.

c. Variabel Quick Ratio dapat digunakan sebagai variabel moderating yang dapat memperkuat atau memperlemah hubungan antara variabel Ukuran 
Perusahaan, Arus Kas Operasi, PBV dan PER terhadap Dividend Payout Ratio pada Perusahaan Manufaktur yang terdaftar di Bursa Efek Indonesia tahun 2008 - 2012.

\section{Saran}

a. Penelitian selanjutnya dapat memperluas populasi penelitian sehingga tidak terbatas hanya pada perusahaan manufaktur yang terdaftar di BEI sehingga dapat memberikan hasil yang memberikan gambaran reaksi pasar modal secara keseluruhan.

b. Penelitian selanjutnya menambah variabel rasio keuangan selain yang digunakan dalam penelitian ini.

c. Penelitian selanjutnya diharapkan menggunakan variabel moderating selain daripada Quick Ratio

d. Penelitian selanjutnya dapat menambah tahun pengamatan menjadi lebih panjang dari lima tahun.

\section{E. DAFTAR PUSTAKA}

Brigham \& Houston, 2011, Dasar Dasar Manajemen Keuangan Essentials Of Financial Management, Buku 2 Edisi 11, Salemba Empat, Jakarta.

Dyckman, Thomas R, Roland E. Dukes, dan Charles J. Davis, 1996, Akuntansi Intermediate, Jilid Dua, Edisi Ketiga, Terjemahan oleh Herman Wibowo, 2001, Erlangga, Jakarta.

Ghozali, Imam, 2005, Aplikasi Analisis Multivariate dengan program SPSS, Edisi 6 Universitas Diponegoro Semarang

Irawan \& Nurdhiana, 2012 Pengaruh Laba Bersih dan Arus Kas Operasi Terhadap Kebijakan Deviden pada Perusahaan yang terdaftar di Bursa Efek Indonesia Periode 2009 - 2010 Sekolah Tinggi Ilmu Ekonomi Qidya Manggal

Kadir, Abdul, 2010, Analisis Faktor faktor yang mempengaruhi Kebijakan Deviden pada Perusahaan Credit Agencies Go Public di Bursa Efek Indonesia, Jurnal Manajemen dan Akuntansi, April 2010, Volume 11 Nomor 1 Sekolah Tinggi Ilmu Ekonomi Indonesia Banjarmasin.
Latiefasari, Hani Diana, 2011, Analisis Faktor faktor Yang Mempengaruhi Kebijakan Deviden (Studi Empiris pada Perusahaan Manufaktur yang Terdaftar di BEI Periode 2005 - 2009)

Lopolusi, Ita, 2013, Analisis Faktor faktor yang Mempengaruhi Kebijakan Deviden Sektor Manufaktur yang Terdaftar di PT Bursa Efek Indonesia Periode 2007 - 2011, Jurnal Ilmiah Mahasiswa Universitas Surabaya, Vol 2 No. 1, Fakultas Bisnis dan Ekonomika Universitas Surabaya

Mariah,dkk, 2012, Pengaruh Profitabilitas dan Kesempatan Investasi terhadap Kebijakan Dividen Tunai dengan Likuiditas sebagai variabel Moderating pada Emiten Pembentuk Indeks LQ - 45 (Periode 2008 - 2010), Seminar Nasional Akuntansi dan Bisnis (SNAB) 27 Maret 2012 Universitas Kristen Maranatha

Manurung Indah Agustina, 2009, Pengaruh Laba Bersih dan Arus Kas Operasi terhadap Kebijakan Deviden Pada Perusahaan Go Publik, USU, Thesis

Purwanti, Dwi, 2012 Dampak Rasio Keuangan terhadap Kebijakan Deviden, Fakultas Ekonomi Universitas Gunadarma.

Sudana, 2011, Manajemen Keuangan Perusahaan Teori \& Praktik, Penerbit Erlangga

Suliyanto, 2011, Ekonometrika Terapan : Teori \& Aplikasi dengan SPSS, Penerbit Andi Yogyakarta

www.idx.co.id

www.sahamok.com 